\title{
THE MILITARIZATION THEORY IN POST-SOVIET RUSSIA: DISPELLING THE PATHOLOGICAL LOOK AT POLITICAL AND ADMINISTRATIVE ELITES
}

\author{
Victor Violier
}

\begin{abstract}
This paper aims, through the specific example of the plenipotentiary envoys - a.k.a. the polpredy, at questioning Law as a legitimate knowledge of the political elite in post-Soviet Russia. The term legitimate has to be understood as both a legitimated and a legitimating knowledge.

A new level of administration was set by Vladimir Putin right after his election in May 2000 and has become a symbol of the militarization of political elites in Russia, concretized by a massive recruitment of people from the so-called power ministries. Beyond this, in the context of a closed institutional game and the power's will to neutralize a whole bunch of the political game's rules, law also becomes a ground on which to build a control of the political and administrative elites' recruitment. Our approach blends a critical overview of the literature and a prosopographical study of
\end{abstract}


more than 20 members of Russian top political elites between 2000 and 2012, corresponding to Putin's three first mandates as the head of the Russian state - two as President and a third one as Prime Minister under Dmitri Medvedev's Presidency.

Our study led us to the conclusion that, not only should we regard Law as esteemed but also, and above all, as invested with an instrumental function by the power in place, but also those who long to be in power.

Keywords: Militarization; law; legitimity; state building; political and administrative elites; political culture

\section{THE OSCILLATIONS OF RUSSIAN FEDERALISM}

The evolution of Russian federalism since the end of the USSR may be compared to that of a pendulum (Gel'man, 2006, p. 104). During the 1990s and the Presidency of Boris Yeltsin - from December 25, 1991 to December 31, 1999 - the power of the different "subjects of the Federation," as the various entities of the Federation are called, continually expanded while the Central power became weaker and weaker. To maintain his power, Yeltsin concluded agreements with the local barons and thus delegated large elements of the state sovereignty to the provinces. This process was particularly accurate concerning the Republics within the Russian Federation. The central power even started to sign bilateral treaties with more and more subjects of the Federation. It started, for instance, with The Republic of Tatarstan on February 15, 1994 (Gazier, 2002, pp. 194-195; Lallemand, 2010, p. 130). In this context, a large number of subjects felt free to adopt local laws, rules, regulations, and policies that were not in line with national laws. Some of those laws were even unconstitutional, regarding the Constitution of the Russian Federation adopted on the December 25, 1993. Therefore, a "transactional federalism" (Gel'man, op. cit., p. 107) or "Federalism on a-case-by-case basis" was born. This led to the conclusion that "During the 1990's, Russia had as many regional political regimes as provinces" (Lallemand, op. cit., p. 131). This asymmetry (Daucé, 2008, p. 46; Lallemand, 2010, p. 130) reached its peak with the financial and economic crisis that occurred in August 1998. The regional executives had become extremely powerful and the obvious inability of the central power to deal with the multifaceted crisis - that was symbolized by 
the collapse of the rouble which resulted in the Russian government and Central Bank devaluing the rouble and defaulting on the debt - raised the question of the federal power's future (Mendras, 2007, pp. 127-132). The nomination of Yevgeny Primakov as Prime Minister in September 1998 was one of the last attempts to restore central power over the provinces. Less than a year later, Yeltsin and his entourage chose Vladimir Putin as the new Prime Minister and, even more, the designated successor to become the second President of the Russian Federation (Gazier, 2002, p. 181; Sakwa, 2008, pp. 121, 123-124).

The Putin Presidency has consisted from the beginning in an authoritative recentralization of power. After being chosen to act as interim President on the evening of the January 31, 1999, Vladimir Putin's position was then confirmed by the presidential election held in March 2000. In fact, after competing as an independent, he was elected in the first round with more than 53\% of the vote out of a total of 11 candidates. Since he came to power, Vladimir Putin has shown his intention to stop the movement of decentralization initiated under Yeltsin's Presidency (Gazier, 2002, p. 203). It was even illustrated while he was still Prime Minister by the invasion of the secessionist Republic of Chechnya that took place on August 26, 1999 and started the second Chechen war in response to the invasion of Dagestan by the Islamic International Brigade (Le Huérou, 2010; Merlin, 2007).

\section{THE ESTABLISHMENT OF THE POLPREDY, HOW THE ROT HAS SET IN ...}

As a newly elected President, Vladimir Putin then put forward two main concepts to symbolize the re-ordering of the State order, and, consequently, of Russian federalism. The first concept is the so-called "power vertical." It consists of implementing a straight hierarchy between all levels of administration, each one obeying to the upper one (Gazier, 2002, 2008; Kossolov, 2007). The second concept is the "dictatorship of law," which comprises two lines. On the one hand, it means that all local and regional laws, rules, and policies now have to match the Constitution of the Russian Federation. On the other hand, it also means that every administration, every company or individual is submitted to the law. This second part has been almost theoretical but has constituted a convenient political weapon for President Putin. A relevant illustration of this was the so-called "Khodorkovsky case" that started after Mikhail Khodorkovsky was 
arrested on October 25, 2003 in Novosibirsk (Siberia) and his company forced into administration by the State. Indeed, the trial of the wealthiest man in Russia at that time - according to Forbes magazine - was a clear demonstration of the State power over individuals and local or national lobbies (Daucé, op. cit.; Favarel-Garrigues, Sapir, \& Rousselet, 2004).

As for policies, Vladimir Putin has introduced several State reforms since he took office. The creation and appointment of the so-called polpredy on the May 13, 2000 is one of them. In fact, he used the presidential decrees (Ukaz) $N^{\circ} 849$ to 855 "O polnomočnom predstavitele prezidenta rossijskoj federacii v federal'nom okruge" to create this new level of the state administration. The polpredy are part of the presidential administration, regularly considered the most powerful corps within the State. There were seven delegates for the entire territory at the very beginning. An eighth one was appointed to the North Caucasian Federal District which resulted from the division of the Southern District decided in 2010 by Dmitri Medvedev after he succeeded Vladimir Putin. The polpredy are supposed to control the actions of the governors and the presidents of the Republics and to ensure that local legislation complies with the State Constitution. We can add that the creation of the polpredy was complemented by additional measures tending to a recentralization of the State power, such as the suppression of direct universal suffrage for the election of the Governors and Presidents of Republics.

In a nutshell, presidential plenipotentiary envoys became the champions of the new centralism (Gel'man, 2006) and the vertical of power since they were nominated to tame the regional entities emancipated during the Yeltsin years. They also serve as an example of the reshaping of the Russian political and administrative elite, from which we can observe both the configuration and evolution of Russian elites since the fall of the Soviet Union.

\title{
THE SHORT-SIGHTEDNESS OF THE MILITARIZATION THEORY
}

\author{
An Attractive Paradigm ...
}

What we see as the "militarization theory" consists in a widespread paradigm dominating a large amount of issues about Russian elites and revolving around the issue of a "militarization of power" (Raviot, 2008, p. 48). Russia is considered a hybrid political regime (Diamond, 2002). Its "degree of democracy" is regularly debated, The Russian political regime being 
thus usually classified between the western liberal "consolidated democracy" (Linz \& Stepan, 1996) and the politically "closed regimes" (Levitsky \& Way, 2002; Schedler, 2002). It is also considered as a "democracy with adjective" (Collier \& Levitsky, 1997): administrated, directed, Potemkin etc. Thus, one of the key aspects that has been widely portrayed by both scientific and media analysts during the last fifteen years would be a so-called militarization of Russian elites. A few months after Vladimir Putin came to power, what we decided to call "The militocratic paradigm" was developed. Indeed, according to most analysts, the arrival of Putin to power has entailed the appointment of an increasing number of people from military structures to positions of power. Thus, according to this analysis, the entire political regime of contemporary Russia has been affected by the massive penetration of military people.

The term 'militocracy' was used for the first time - to our knowledge by Olga Krychtanovskaya and Stephen White. In an article published in 2003 in Post-Soviet Affairs and entitled "Putin's Militocracy," they clearly insist on what they consider a major transformation in Russia since the 2000s. Their statement is doubly linked to the incoming of numerous military personnel. Firstly, they consider that Vladimir Putin has played a major role in the recruitment of his previous colleagues at every level of administration. Therefore, this penetration would be the result of a well-planned policy from the newly elected President to secure his position by reshuffling the administration main body. Secondly, this reshuffling would affect even the form of the state and the political regime of Putin's Russia. It would put an end to Russia's transition to democracy and create a military regime. As an example of this decisive conceptual shift in meaning, we can quote the title of an article from The Economist magazine published in 2007: "The Making of a New KGB State." At the core of the article the author asserts "Men from the FSB and its sister organisations control the Kremlin, the government, the media and large parts of the economy - as well as the military and security forces. (...) The KGB provided a crucial service of surveillance and suppression; it was a state within a state. Now, however, it has become the state itself" (The Economist, 2007, §4, §6). It might also be added that the edition concerned is even entitled "Putin's people. The spies who run Russia." In the same way, some researchers went so far as to warn against "a peaceful military takeover" (Petrov, 2002) happening in Russia as soon as "the institution of the envoys is one of the major elements within the new Putin model of replacing state institutions with substitutes" (Petrov, 2005, p. 56): "A year and a half may be too short a period for definite conclusions, but one thing that is already sufficiently clear is that, whatever the Kremlin's initial plans and 
words, what is really happening is the insertion of police-state mechanisms into a delegative and declarative democratic state (...) Putin's aim is to create a strong state under his leadership; everything else - including de-democratization and de-federalization - is mere side-effect" (Petrov, 2002, p. 82).

Thus, the characteristics of the military people would influence their way of ruling the administrations and, therefore, the whole state. The values and attitudes that they acquired within the security forces determine their actions whilst in power. This matches with the work of Mills (1956), who wrote in this respect, in The Power Elite, that military people did not lose the effects of both the education and training that modeled their personality and their vision of the world. Meanwhile, this perspective could also be reversed. Indeed, instead of considering only a militarization of politics, couldn't we think of a civilization - in the sense of a "politization" - of the military area? It would result in us taking into account the politization of military people and security forces as well as law enforcement organizations. We think here of Jean Joana's reflexion about the position of military personnel and their relation to power mentioning among other Alfred Stepan's writings about Brazil and the example of the Escuela superior de Guerra $(1971,1973)$. Actually, the military might become so bogged down in politics that it would neutralize their ability to be a problem for the government. For instance, the sociology of comparative politics has been reluctant to consider "military regimes" as a category of regime in itself. Indeed, Linz (1985) has already suggested, the nature of these regimes cannot be reduced to the military origin of those who rule, since their influence tends to fade while the regime is stabilizing (Joana, 2006, pp. 7-9).

The quantitative dimension of the "militocratic paradigm" has been demonstrated. The calculations have certainly been well overestimated at the very beginning and have favored a catastrophic outlook (see Rivera \& Rivera, 2008 revising data of Kryshtanovskaïa \& White, 2003). Still, it seems that this dimension is globally attested. According to the data of Rivera and Rivera (2008) one in eight members of the Russian administrations has served in the power ministries. And this number has increased by $25 \%$ since Vladimir Putin came to power. As a consequence, the aim of our paper is not to contradict the data but to question the qualitative dimension of it. In other words, to what extent has Russia become a militocratic regime?

\section{... But a Distorting Prism to Look at Russian Elites}

Beyond a normative and pathological look, a closer look at plenipotentiary envoys' career paths shows variety and diversity. Our empirical research 
consisted of a prosopography of all the polpredy (24) who have been in office since the creation of the function in 2000 until May 2012. The study of the biographical characteristics of these individuals is a good way of analyzing the role of the cultural factor in the process of distinction of Russian elites since Vladimir Putin came to power. In fact, they are both the personification of the "new centralism" and the "vertical of power" and an example of the reshuffling of Russian elites since the end of the Soviet era. Thus, the empirical work consisted of compiling information and data from various sources to compose, as far as possible, the most detailed biography for every individual that has been in office within this administration between 2000 and 2012. The year 2000 refers to the first election of Vladimir Putin and the creation of the function of the polpredy in May. May 2012 refers to the third election of Vladimir Putin after Dmitri Medvedev's term. The election took place in March, he then entered into office on May 7th. This period includes a total of 24 people.

We started using the biographical information we could find form the two main sources edited in Russian (Chchegolev, 2008; Muhin et al., 2004). Then, we updated and cross-checked these informations with both institutional and non-governmental websites - such as the official websites of the federal districts administration and independent journalists' websites - such as kompromat.ru, for instance. Concerning the nature of the two principal sources, we would like to assert that they are different from the main AngloSaxon reference which is the biographical dictionary entitled The Who's Who. Actually, if they both highlight identity-building strategies of the politicians, our sources are more based on a bureaucratic than "worldly" model (Collovald, 1988). They include all the high-level officials and bureaucrats and detail their careers in a chronological and very official way.

The analysis of our empirical materials allows us to contrast sharply with the caricatural and homogeneous vision of Russian elites given by the militocratic theory. To begin with, it is important to underline that not only the career paths but even the mandate trajectories of the polpredy have been very diversified since these representatives were nominated and dismissed on the decision of the only President of the Federation. Firstly, some of the polpredy have been nominated in two different districts over the 12-year period of time we are considering. Secondly, the duration of the 24 polpredy's term of office has varied between 6 months and more than 11 years. The average duration of the term of office has been three and a half years.

We paid attention to the recruitment and departure conditions. Indeed, the function of the polpred is unequally linked to governmental positions. Seven of them occupied a position within the government when they were 
nominated as a polpred. Nevertheless, they didn't have similar positions. For instance, Oleg Safonov (polpred in the Far-eastern district from 2007 to 2009), deputy Minister of the Interior (MVD) before his nomination, was far lower in governmental hierarchy than Valentina Matvyenko (polpred in the North-Western district in 2003), since she was herself deputy Prime Minister. The future of the polpredy after their mandate is also very different. In fact, only four of them have been directly nominated in the government while some started running state-controlled agencies and companies or were nominated in the regions, for instance as governors.

Center-region or region-center pathways are also hard to unify. In fact, three of the 24 polpredy used to be governors of some subjects of the Federation, that is, part of the regional administration before being nominated in the Presidential administration. V. Ishaev has served as Governor of the Kraï of Khabarovsk from 1991 to 2009 before becoming polpred of the Far-Eastern federal district. A. Khloponin was in office in Krasnoyarsk for 8 years when he was nominated in 2010 to rule the North Caucasian federal district. Finally, V. Tolokonsky was the head of the oblast of Novosibirsk for 11 years before his nomination as the new polpred of the Siberian federal district in 2010. On the contrary, two polpredy were transferred from the presidential - central - administration to the regional administration. Thus, V. Matvyenko, the only woman who has occupied the post of polpred, became Governor of St-Petersburg after her very short term in office as the polpred of the North-Western federal district in 2003. G. Poltavchenko occupied the same function as Matvienko after he was dismissed from the post of polpred of the Central Federal District. As a consequence, it is hardly possible to think in terms of "political spoils" (Bailey, 1969), and establish a hierarchy of national and regional functions in which we could replace with precision the polpredy.

The most important aspect highlighted by the large diversity of the polpredy's career pathways is certainly their professional background. Indeed, it results from a detailed analysis of the various professional positions occupied by the polpredy before their coming in office that three major groups could be distinguished. This strongly undermines the militocratic theory, not just because only eight of the twenty four polpredy have been working within the power ministries but also because even these eight individuals are far from having such a common professional identity.

Therefore, the first group of individuals that can be identified is composed of eight individuals who have worked in the so-called power ministries. Thus, they are considered as being part of the so-called siloviki. Among these eight individuals that have worked in the power ministries, four have served 
in the KGB and/or for its successor the FSB. V. Tcherkesov is a former colonel general of the KGB and was the Deputy Director of the FSB. G. Poltavchenko is a former officer of the KGB and was the head of the Direction of the Federal tax police in Saint-Petersburg. G. Rapota worked in the First General Direction of the FSB (foreign intelligence) and was involved in long-term missions in western countries. Finally, O. Safonov, a former KGB agent, has been decorated with the Order of the Red Flag of the KGB Institute of the Soviet Union. Then, three individuals are former professional soldiers. Indeed, V. Kazantsev, K. Pulikovskiï, and A. Kvashnin are respectively General in Chief, Lieutenant-General, and Colonel General of the Russian army and have served in various conflicts such as the war in Afghanistan or the two Chechen conflicts. Lastly, we can add P. Latyshev, who is a former Colonel General of the Ministry of Interior of the Russian Federation (MVD).

Sixteen of the polpredy (2/3) thus have a different professional origin. Indeed, nine of the plenipotentiary representatives occupied an intellectual profession or were former senior managers in the Civil service. Among them were four former magistrates, three former University Professors, and two former senior civil servants. They consist of the second identifiable group. The third and last group is composed of five plenipotentiary representatives who came from the business sector. They were all leading banks and/or industries - such as Noris Oïl or Noris Nickel - during the 1990s. Finally, we could notice here that two trajectories do not match with our categorization: V. Matvienko and K. Ishakov had particular career paths that we will analyze further.

The close look we just had at the plenipotentiary representatives career path allows us to have a more nuanced picture of these individuals than the one depicted after V. Putin's coming into office and that we described before. It also invites us to consider siloviki as a polysemic notion that should be debated. Therefore, if five out of the seven first polpredy were former members of the power ministries, there were "only" eight out of 24 twelve years after the introduction of their function. Nevertheless, it still corresponds to a third of the total. Consequently, it would still be possible to consider that this new level of administration is a testimony of the "military takeover" (Petrov, op. cit.) that has occurred since V. Putin came to power in 2000, without any further examination. This is the reason why we currently need to develop our analysis on the nine key individuals known as former power ministries members, that is, siloviki.

Firstly, the notion of siloviki itself - as well as the one of power ministries - should be debated (Bacon, Cooper, \& Renz, 2007). The concept of 
siloviki products a homogeneous reality. It thus tends to lead to the conclusion that, for instance in the case we are interested in, the eight individuals who have worked in the power ministries are broadly similar to each other. Nevertheless, it is now time to assess this problematic notions of "silovik" and "power minister." To summarize on this issue, a relatively consensual and operational definition has already been established as follows: "The power ministries in Russia are those state agencies in which the personnel generally wear uniforms and in which some people carry guns. More precisely, those bodies are military, security or law enforcement bodies that possess armed units of formations. People with power ministry backgrounds are referred to as siloviki" (Taylor, 2007, p. vii). However, as Edwin Bacon, Julian Cooper and Bettina Renz noted: "The concept of a silovik, though an attractive shorthand term, masks wide-ranging differences between those who are labelled with this epithet. A silovik could have served in a diverse group of force structure (for examples, the military, the police, the intelligence services), in a diverse range of roles, at different level of seniority, in different periods, and for differing lengths of time. There are democratic siloviki, and authoritarian non-siloviki" (Bacon et al., 2007, pp. 42-43). We could not agree more to the three authors' statement in this case. The notion of silovik actually functions as a stereotype that smoothes out asperities and erases the differences between trajectories that can be particularly various, providing a distorted vision of the reality. As a consequence, there might be more differences than similarities between some or the totality of the individuals categorized as siloviki.

Secondly, a careful look at the recent political history of the Russian Federation might also help us to put this particular recruitment back into its context. Indeed, when Vladimir Putin was chosen as his successor by Boris Yeltsin and the so-called Family - as the Yeltsin entourage has been nicknamed - he only had a few months experience on the national political stage (Daucé, 2008, pp. 60-62). Besides, he was not affiliated to any of the political parties existing in Russia. Therefore, he could not recruit in a political party's reserve of individuals and had no other choice but to rely on the individuals he already knew through other ways (Solovev quot. in Renz, 2006). That is why he decided to rely on people he used to know by working with them either in the security forces or in the St-Petersburg City council where he started his political career, after the fall of the Berlin wall. We can add that when Boris Yeltsin came to power, he proceeded the same way, nominating people from his hometown, Sverdlovsk, to assume various strategic positions (Kryshtanovskaïa \& White, 2003). Actually, we can use the comparison of Alekseï Salmin, Director of the Russian Centre of 
Public Policies: "Of course Putin relies on those he understands and knows. This is absolutely natural. If a professor happened to become president, he, too would invite some people from his environment" (quot. in Renz, 2006).

According to this point of view, the professional socialization of Vladimir Putin would explain the nature of his recruitment. That might be a reasonable explanation. Nevertheless, this cannot be the only valuable explanation for the large amount of people from the power ministries coming to power on both national and local scales. Consequently, the introduction of the cultural factor has to go further than an insight into Vladimir Putin's professional background.

\title{
CONSIDERING RUSSIAN ELITES BEYOND THE MILITARIZATION
}

\author{
The Cultural Factor as an Alternative Clue
}

The cultural factor will be studied in two steps in order to put forward an alternative explanation to the militarization theory - which makes the incursion of the military in Russian politics a concerted plan. On the one hand, the elite culture of liberal democracy - especially in western countries but also among Russian intellectual elites - explains the development of the militarization theory. On the other hand, the Soviet cultural legacy in Russia might be a clue to understand the reshuffle of Russian elites about the law around the beginning of the XXIst century.

The culture of liberal democracy has been playing a major role in the construction of the militarization theory. Thus, before discussing the findings of the prosopography concerning the cultural factor, we have to consider the cultural aspect of the knowledge on democracy and more specifically on transitions to democracy. In fact, the topic of elite political culture - understood as the circulation of cultural knowledge concerning transitions to democracy - helps to have a better understanding of both the construction of Russia's attitude toward democracy and the future collective political behavior in Putin's Russia. Thus, considering the cultural dimension of politics allows to complete the deconstruction of the militocratic paradigm. That is the reason why we need to identify deeply both its theoretical and contextual origins, that are closely related to the production of democratic knowledge. The militocratic paradigm is, by and large, a construct of analysts' pathological look at the Russian political regime and, 
therefore, at the Russian elites. Although transitology as well as all theories of democratization have been widely discarded, the fact remains that they still have effects on the field of comparative politics and political regimes analysis. The main objections that have been raised against transitology and its grip on comparative analysis of political regime change might apply to the militocratic paradigm. Indeed, transitology suggests that liberal democracy is the end of the transition process which, by the way, is placed at the very core of the analysis. Its normativity, that comprises sometimes a very prescriptive dimension, has had a strong influence on the production of knowledge on the new-born Russian political regime since the end of the 1980s. Yet, if liberal democracy is considered an ideal in terms of political regime, the Russian political regime is to be regarded, at least, as an incomplete or imperfect one (1990s), or even as an antithesis or a concurrent model (2000s). As a consequence, Putin's Russia has been gradually observed from a pathological standpoint. According to it, Russia got lost on its way toward democracy. This has become particularly obvious since Vladimir Putin came to power because he departed from the liberal and pro-western policy of his predecessor.

It seems that some of the main objections made to transitological approaches (see for instance Carothers, 2002; Dobry, 2000a; Zalewski, 2009) should be reinvested to discuss the pathological look at both Russia's political regime and the elites. For instance, the tree structure used by Przeworski (1979) in The Games of Transition to describe the sequence of choice-situations on the path to democracy represents the finalist aspect of transitology. It has been demonstrated that one should rather question the process of social and political reproduction explaining the original forms of the State in postcommunist societies (Dobry, 2000b). It is a matter of restoring the importance of political structures while transitology is only centered on political actors and their strategies. Transitology also emphasizes the gap between the historical path of postcommunist societies toward democracy and the ideal democratic path by conceptualizing it. This gap approaches the gap that Bailey (1971) put in evidence between normative and pragmatic rules. On the one hand there are general political guidelines. On the other, there are goal-oriented leverages and tactics.

Last but not least concerning the issue of democratic knowledge, a careful look should be given to the study Guénard (2007) made on the debates held in the field of democratization studies in the United States and more particularly within the Journal of Democracy. The author first notes that the Journal was created on R. Reagan's initiative at the beginning of the 1980s and was intended to be the fundamental guide during the war of 
ideas with the Soviet Union. Thus it aimed at supporting the export of the "democratic model." Indeed, its founders M. J. Plattner and L. J. Diamond, both close to the American neo-cons, wanted to challenge the ideologies of authoritarian and totalitarian States with a militant support of democracy. The journal was supposed to favor the expression of a "science of democracy." Yet, this ideological end encouraged theoretical reshuffles such as the creation of the concept of consolidation that renewed and consolidated the transitologic paradigm. Nevertheless, the theoretical inputs that came with the notion of consolidation did not modify the objections we already expressed. For instance, the confirmation of the existence of "hybrid regimes" (Diamond, 2002) does not change the fact that the analysis is relying on a one best way. Political elites are still regarded as pluralistic and stratified elites remain the norm of democratization as, for instance, in the analysis of the relations between elites and political regimes (see, e.g., Carothers, 2002, p. 301; Genieys, 2011, p. 266 where Russia is associated with China, Cuba, North Korea, and Iran as a country where the "political elite is (until then) ideologically unified," p. 300). Elites are indeed, in this conception, made to compete with a large variety of capitals. It might sound quite normative to consider that Russian elites are supposed to become pluralistic. It results in two main effects. It first suggest that they are perfectly ideologically unified at the moment, which deeply underestimates the complexity of relations and interactions not only between the various configurations of elites but also within each of them. It secondly implies that Russia is lagging behind comparing to the West which is supposed to embody political modernity.

Nonetheless, it must be acknowledged that, after a period of hesitation about the way Russia should follow to make its transition, the new team that came to power in the end of 1999 quickly ensured the shutdown of the political game. Following on from Juan J. Linz about authoritarian regimes (1985), academics such as William Genieys (op. cit.) tend to attach authoritarian regimes to a limited elite pluralism. This reinforces the pathological look at Russian elites as a consequence of the analysis of Russia's political regime. We in fact assume that Russian political elites are commonly evaluated in reference to the incompleteness of its democracy. Furthermore, all these developments fit in perfectly with the militarization theory which is essentially based on the idea that Russian elites have become strikingly homogenized - since Vladimir Putin came to power in 1999 - around a common military ethos. It has been finally corroborated in the course of both journalistic and scientific narratives focused on the victory of the former KGB members over the liberal democrats and the reformers. As a 
consequence, the analysis of elites in post-Soviet Russia, where the competition is restricted and favors the reproduction of an oligarchic elite linked by stable collusions, makes Russia a black sheep among modern western democracies that are legitimated by a knowledge they developed across the world's political, diplomatic, and scientific fields (Wagner, 2007).

\section{Reconsidering the Reshuffle of Russian Elites}

Considering the issue of the cultural factor to think about both political elites and political regime changes in Post-Soviet Russia is to establish the preliminary basis of a more nuanced reading of their evolution since the fall of the USSR. The cultural factor is not only a way to identify how the militocratic paradigm is an obstacle to the analysis of Russian elites. It is also a clue to identify a more relevant binding agent between them. As we saw, one of the interests of the analysis of the career paths of the 24 polpredy who have been in function from 2000 to 2012 is to underline the heterogeneity of a particular body of the presidential administration behind a homogeneous representation. Besides, it allows us to go beyond the identification of the militocratic paradigm. In fact, asserting that answering Robert Dahl's famous interrogation - "Who governs?" (1961) - is a harder that it looks concerning contemporary Russia, does not mean that we cannot find some clue.

Back to our corpus, some career paths make it clear that a continuity exists among Russian political elites between the Yeltsin era and the Putin era. This is in line with some major theoretical contributions provided on central and eastern Europe (Mink \& Szurek, 1999) and Russia (Szelenyi, Wnuk-Lipinski, \& Treiman, 1995) which analyses former high-ranking communist cadres' career paths after the fall of the Berlin wall and more specifically their retraining in politics and economy. For instance, trajectories such as the one of S. Kiriyenko confirm the continuity between the Yeltsin and the Putin years. A former high-ranking official of the CPSU during the 1980s and then close to the late B. Nemtsov - former liberal politician who was one of Yeltsin's lieutenants - in Nizhny-Novgorod, he became Prime Minister in 1998 when Yeltsin was President of the Russian Federation. He was one of the founders of the Union of Right Forces (SPS) which was the main political movement of the right-wing liberals created in 1999. He then became the first polpred of the Siberian Federal District after V. Putin came to power. We can consider his term was a success since V. Putin then named him to become the head of the Federal Atomic Energy Agency (Rosatom) when it was created in 2005. He is now 52 years old and is still in office. 
This example of a liberal politician of the early 1990s recruited by V. Putin fights against the idea that military people erased the past, shunting Yeltsin years' liberals into early retirement. We might also give the example of G. Poltavchenko who was the first polpred in office in the Central Federal District. He had been chosen, before, to act on behalf of Yeltsin in the Leningrad oblast under the previous administration.

Highlighting these trajectories, we cannot help trying to understand how V. Putin gathered such different people in this state administration body and globally in his political entourage. What kind of vector of "the unity in diversity" (Highley \& Pakulski, 2000, p. 658) - did V. Putin find to make everyone pull together? It seems to us that law is part of the answer even beyond the concepts of dictatorship of law and power vertical (see below). Keeping in mind the importance of both historical and geographical context in the study of transitions and regime change (Bunce, 2000) a look should be taken at the political, economic and social developments of the late 1990s in Russia. In the generalized crisis context corresponding to Putin's coming to office, the power elites have been developing a legal discourse to insure their own legitimation. This part of the work has been especially symbolized by Vladislav Surkov's ideological work within the Kremlin and the two main concepts we already talked about - the vertical of power and the dictatorship of law - aimed at building a "sovereign" or "managed" democracy (Laruelle, 2010).

The concept of "sovereign democracy" set up by Vladislav Surkov is indeed helpful to portray not only what is assumed to be the practical gap between Russian regime and the ones in western countries but also the theoretical conceptualization of differences between democracy in Western understanding and the Russian regime. The epithet concentrates on the Surkov ideological construction intended to justify Russia's choice to take a different path, leading away from the Western conception of the liberal democracy as claimed in particular by the US and the European Union State members. The sovereign democracy should firstly be seen as a reaction - not to say reflex - from the Russian head of state to the colored revolutions that happened in Georgia, Ukraine and Kyrgyzstan between 2003 and 2005. This revolutionary wave in several former Soviet Union countries was indeed interpreted by the Russian power as the result of various external interferences from the West. It is then supposed to show everyone - and especially the United States - that no foreign interference will ever be tolerated. Then, Surkov's concept has to be understood as a subtle blend of Russia's political past and historical conquests. It actually insists on the nationalist dimension and is based on a positive vision of the country's past, highlighting for 
instance the successes and achievements of the Soviet era. As M. Laruelle details it (op. cit., p. 228): the Soviet Union was sovereign but not democratic, Russia during the 1990s was democratic but lost its sovereignty, Vladimir Putin's Russia is supposed to reconciliate these two main orientations. Finally, this ideological construction aims at embodying political modernity and the future of the Russian society in a globalized and evolving world which requires every country to be open to develop. To conclude on this point, we can contend that Vladislav Surkov's concept of sovereign democracy serves two main goals: on the domestic side, it is used to justify and defend its own path to democracy; at an international level, it can be considered a competing offer, especially intended to Russia's partners that might be willing to escape the US or EU influence such as India, China or even some countries in eastern Europe, as Polish political events of the beginning of 2016 suggest.

Accordingly, recruiting people who have competencies in both law and law enforcement would have made sense for the team in power in addition to the questions of prestige and sociability networks (Raviot, 2006, pp. 48-52). Then, the recruitment of people from law enforcement bodies would not be due to their military background but to the fact that the power in place actually believes that they master knowledge and know-how related to law. This hypothesis actually corresponds to some classic theories of the State's construction in Political science and refers to the classic notion of the rational-legal authority (Weber, 1971). Law is thus valued and the power in place needs personnel that are familiar with it, not to say specialists. Accordingly, specific knowledge and know-how connected with legal training and sociability networks as well as a particular position within judicial field would make some individuals particularly valuable resource persons. In this respect, judicial and legal fields are considered as "positional" spaces or areas (Boltanski, 1973; Passeron, 1990) and the construction of a monopoly on a complex knowledge - legal, in this case - must be regarded as a key factor to ensure social power (Konrad \& Szelenyi, 1979). Considering our corpus, we can mention that not only is law at the core of the education and training in law enforcement bodies, but also four of the polpredy are former magistrates. N. Vinnichenko, V. Ustinov, D. Kozak, and A. Konovalov all worked in the General Prosecution both in Moscow and the regions. This hypothesis might be further investigated on the basis of the model provided by some research conducted on the EU staff members (see for instance Cohen \& Vauchez, 2005).

In fact, not only do we consider knowledge stricto sensu but also knowhow and skills as well as interpersonal relationships, cultural background 
etc. that generate a "entre-soi." It results from this that individuals and groups of individuals revolving around law in Russia could not be limited to lawyers or other legal experts. Those knowledge lato sensu then logically comprise everything referring to the notion of habitus (Bourdieu, 1980) of theses elites. Such resources provide cultural capital/asset, that comes in three "forms": "incorporé"|"embedded," "objective"/"objectified," and "institutionnalisé"/"institutionalized" (Bourdieu, 1979, pp. 3-5). Elites are arising, in this regard, from this shared bedrock of cultural asset: "Belonging to an Elite implies mastering its behavior codes, its language, its relationships that shape modes of sociability (...) It also implies having a specific field of competence and being endowed with a particular knowhow"... (Leferme-Falguières \& Van Renterghem, 2000, p. 63).

Furthermore, the power's ideological and political discourse emphasizing the importance of law and legality seems to be in line with political modernity and must be endorsed by international political elites. A sample of the international reactions to D. Medvedev's coming to power in 2008 which was actually a highly fictional succession - is indicative of this wideranged acceptance. Lawyer by training and former University teacher of roman and civil law, he was supposed to be a very good match for the globalized intellectual elite since they were assuming that he was a part of it. Nevertheless, Dmitri Medvedev's policy as a President of the Federation showed the relativity of his modernity discourse. This is especially true knowing that V. Putin introduces himself as a modernizer since his very first term in office.

Furthermore, we might postulate the relevance of the connection with Charles' Tilly's work (1992) on coercion - associated with capital - in state development in Europe and the leading role of war or, at least, its preparation - whether from a practical point of view or at a symbolic and discursive level. According to C. Tilly, the establishment of an army generated a stable state structure and the preparation of war has been the source of internal structures of the European states. However, he highlighted a militarization-civilization process after which the civilian bureaucracies and assemblies regain control over military people and structures. Yet, this process is not supposed to consist of a compulsory step of the states' development. In this perspective, Tilly's work emphasizes the parallel existence of states where militaries remain on the top of power, especially when institutions led by civilian people have failed. In the case of Russia, the 1990s can be considered as the failure and disrepute of civilian and democratic institutions. Russia's contemporary regime is then, again, considered in pathological perspective since the civilization is regarded as missing or failed. The 
constant references to the rule of law might be seen as a countervailing measure to ensure the existence of a civil State.

\section{LAW AS A RELEVANT ELEMENT OF POLITICAL ELITES CULTURE TO BUILD A "SOVEREIGN DEMOCRACY"}

According to N. Elias' fundamentally relational conception of the society (1981), the social equilibrium of forces results in the interdependent relationships that occur among elites and are related to the law. We are prone to think that although the existence of a common habitus of silovikis making them a homogeneous category is hardly relevant, the power in place may have developed a common belief in the existence of a common ethos relying on law and legality among political and administrative elites. In other words, whether or not these common characteristics and shared values are an illusion of the team in power, it seems that they bet on building their authority and power on it. This belief might be scrutinized in the light of M. Dobry's concept of "confidence in the habitus" (1992). It means that people in power and V. Putin in particular are betting on what they assume to be the habitus of the individuals they recruit. According to the representation that they have of them, they are "the men for the job," the ones that should be trusted in a context of crisis - that is, a context of overturning of the institutional references.

It is hard to identify a coherent ideological construction in today's Russia except for a common denominator based on a massive and multifaceted nationalist reinvestment (Laruelle, 2010). It is worth noting in this regard that scholar books are currently being rewritten, as demonstrated by V. Putin's recent project to edit a common textbook for all Russian students of classes nine and eleven (that students usually attend when they are 15 and 17). This emerging enterprise already aims at presenting an idealized and pacified vision of the Soviet era (Konkka, 2014). According to the same logic, Law might play a role as the "lowest common denominator" and a symbolic resource for the elites in Putin's Russia. Putin came to power while Russia was in the middle of a political, economic and social crisis that followed the collapse of the USSR. Both the discourse and action increasingly valued law and legality, partly through revaluation of the Soviet cultural heritage. For instance, Vladislav Surkov, who was for a long time the personal spin doctor of V. Putin and is considered to be "the 
man behind" the Presidential party United Russia as well as the concept of the sovereign democracy, has made clear that the power wants to repeat not the warrior rhetoric but the discourse of modernization of the Soviet Union (Surkov, 2007). Since 2000, the social and political consensus around V. Putin resulted in both the comeback of economic growth mostly due to the huge increase of oil prices - and the promise of a return of State authority. The team in power has been gradually looking for an ideological contribution to replace the economic aspect of the pact. Indeed, the economic crisis of 2008 and the first massive demonstrations of winter 2011 revealed the need of such a bind, not only among elites, but also between elites and the rest of society (Le Huérou, 2012).

Considering this ideological construction and the bet of the team in power on a common commitment to law and legality, the Soviet legacy must be taken into account. Actually, this may particularly be seen as a generational effect among elites. Almost all of the 24 polpredy come not only from the secondary and higher education system but also from the training bodies of the USSR's and CPSU's cadres. Two of them even made all of the "Soviet part" of their career within the CPSU organs. In fact, V. Mativienko started in the komsomols and gradually rose to the top of the Party from 1972 to 1986 when she became Deputy President of a Soviet District Executive Committee in Leningrad. Khamil Ishakov also made a name for himself within the Party by becoming the Head of the City of Kazan. He even stayed in office after the fall of the Soviet Union since he was the mayor of Kazan until 2005.

The 24 polpredy were on an average 35 years old when the USSR collapsed. They were then at the middle of their professional careers and already deeply involved in their personal paths. A majority of them have been awarded by Soviet honorary prices and medals that made them "Heroes of the Soviet Union" for instance. Their personal and individual socializations have been deeply influenced by their experience of the communist regime and the main role assigned to legality and the law. The Socialist legality is a legacy of Lenin's "revolutionary legality" and was renamed as soon as Stalin came to power. Its concept was to give to an undemocratic political system a formal democratic frame (Ginsburgs, 1957; Lavigne, 1980). As far as we are concerned, the continual reference to law in today's Russia can be seen as a legacy of this design. Indeed, the Soviet concept of socialist legality helps us to understand both how political culture is significant in unifying political and administrative elites and how it may be identified as a common denominator beyond the opposition of democratic and autocratic. 
The militarization theory we highlighted might distract from a more complex - and classical, assuming it follows Max Weber's conception of legalrational authority - process of legitimation of power in post-Soviet Russia: using law as an instrumental resource. As French sociologist B. Pudal, drawing on various works of historians, wrote about the concept of totalitarianism in the specific case of Soviet Union, we consider the militarization theory to be a "smokescreen-concept" (Pudal, 2009, p. 164). The establishment of the plenipotentiary envoys in 2000 has clearly been regarded as a personification of the movement of "recentralization" of power. The prosopographical review though strongly shades the militarization thesis and allows to escape the "militocratic paradigm" as we understand it. In order to legitimate its policy, the power in place instrumentalizes both the law and the relation to legality in the political and administrative fields. By historicizing the process of reshuffling of the elites in post-Soviet Russia since the end of the 1980s and the Gorbatchevian perestroïka, we can bring up the idea of a reinvestment of the socialist legality by the power in place. According to this concept, we could assume that the group in power bets on sort of an elite ethos grounded on a common commitment to law and considers this bet an efficient political strategy.

\section{REFERENCES}

Bacon, E., Cooper, J., \& Renz, B. (2007). Securitising Russia: The domestic politics of Vladimir Putin. Manchester, NY: Manchester University Press.

Bailey, F.-G. (1969). Stratagems and spoils: A social anthropology of politics. Oxford: Basil Blackwell.

Bailey, F. G. (1971). Les règles du jeu politique: étude anthropologique. Paris: Presses universitaires de France.

Boltanski, L. (1973). L'espace positionnel: Multiplicité des positions institutionnelles et habitus de classe. Revue francaise de sociologie, 14-1,3-26.

Bourdieu, P. (1979). Les trois états du capital culturel. Actes de la recherche en sciences sociales, 30(novembre) 3-6 (L'institution scolaire).

Bourdieu, P. (1980). Le sens pratique. Paris: Éditions de Minuit.

Bunce, V. (2000). Comparative democratization. Big and bounded generalizations. Comparative Political Studies, 33(6-7), 703-734.

Carother, T. (2002). The end of the transition paradigm. Journal of Democracv, 13(1), 5-21.

Chchegolev, K. A. (2008). Kto est' kto $v$ Rossii. Ispolnitel'naia vlast'. Moscow: Izdatel'stvo Astrel'.

Cohen, A., \& Vauchez, A. (2005). Les juristes et l'ordre politique européen. Critique Internationale, 26, 97-158.

Collier, D., \& Levitsky, S. (1997). Democracy with adjectives: Conceptual innovation in comparative research. World Politics, 49(3), 430-451. 
Collovald, A. (1988). Identités stratégiques. Actes de la recherche en sciences sociales, 73(juin), 29-40 (Penser la politique - 2).

Dahl, R. (1961). Who governs? Democracy and power in an American city. New Haven: Yale University Press.

Daucé, F. (2008). La Russie post-soviétique. Paris: La Documentation française, coll. Répères.

Diamond, L. J. (2002). Thinking about hybrid regimes. Journal of Democracy, 13(2), 21-35.

Dobry, M. (Ed.). (1992 ed. 2009). Sociologie des crises politiques. La dynamique des mobilisations multisectorielles. 3e édition revue et augmentée, Paris: Presses de Sciences Po.

Dobry, M. (2000a). Les transitions démocratiques regards sur l'état de la transitologie. Introduction. Revue Française de Science Politique, 50(4-5), 579-584.

Dobry, M. (2000b). Les voies incertaines de la transitologie. Revue Française de Science Politique, 50(4-5), 585-614.

Elias, N. (1981). Qu'est-ce que la sociologie. Paris: Presses Universitaires de France.

Favarel-Garrigues, G., Sapir, J., Rousselet, K., ... et al. (2004). La dictature de la loi. Paris: Alternatives économiques, coll. L'économie politique.

Gazier, A. (2002). Le bouleversement des institutions et de la vie politique. In D. Colas (Ed.), L'Europe post-communiste. Paris: PUF.

Gazier, A. (2008). Le Président de la Fédération de Russie et l'instauration d'une "verticale executive". Revue d'études comparatives Est-Ouest, 39(2), 73-92.

Genieys, W. (2011). Sociologie politique des élites. Paris: Armand Colin, Collection U Sociologie.

Ginsburgs, G. (1957). Socialist legality' in the USSR. since the XXth party congress. The American Journal of Comparative Law, 6(4), 546-559.

Gel'man, V. (2006). Возвращение Левиафана? Политика рецентрализации в современной России. Полис, 2006, N2, С.90-109.

Guénard, F. (2007). La promotion de la démocratie: une impasse théorique? La vie des idées, 28 novembre.

Highley, J., \& Pakulski, J. (2000). Jeux de pouvoir des élites et consolidation de la démocratie en Europe centrale et orientale. Revue française de science politique, $50(4), 657-678$.

Joana, J. (2006). Le pouvoir des militaires, entre pluralisme limité et démocratie. Communication au Congrès de l'AFSP. Retrieved from http://www.afsp.msh-paris.fr/ activite/2006/colllinz06/txtlinz/joana1.pdf.

Konkka, O. (2014). La recherche d'un modèle de présentation de l'histoire soviétique dans les années 1990-2000: l'exemple du manuel scolaire Histoire de la Russie XXème - début XXIème siècles d'A. Danilov, L. Kosulina, M. Brand. La Revue Russe, (42), 97-106.

Konrad, G., \& Szelenyi, I. (1979). The Intellectuals on the road to class power (1st ed.). Paris, Seuil: Harcourt Brace Jovanovich.

Kossolov, V. (2007). Vertical administrative: Fondements et obstacles. Outre-Terre, 2007/ 2(19), 149-162.

Kryshtanovskaïa, O., \& White, S. (2003). Putin's militocracy. Post-Soviet Affairs, 19(4), 289-306.

Lallemand, J.-C. (2010). La mise au pas des pouvoirs régionaux. In K. Rousselet \& G. Favarel-Garruigues (Eds.), La Russie contemporaine (pp. 129-143). Paris: Fayard.

Laruelle, M. (2010). Le nouveau nationalisme russe. Paris: Editions de l'Euvre.

Lavigne, P. (1980). La légalité socialiste et le développement de la préoccupation juridique en Union Soviétique. Revue d'études comparatives Est-Ouest, 11(3), 5-20. 
Le Huérou, A. (2010). Un Etat en guerre. La Russie et le conflit russo-tchétchène. In La Russie contemporaine (pp. 145-156). Paris: Fayard.

Le Huérou, A. (2012). Les mouvements de protestation: une nouvelle génération dans la rue. Février. Online working paper. Retrieved from http://www.ceri-sciences-po.org

Leferme-Falguières, F., \& Van Renterghem, V. (2000). Le concept d'élites. Approches historiographiques et méthodologiques. Hypothèses, 4(1), 55-67.

Levitsky, S., \& Way, L. (2002). The rise of competitive authoritarianism. Journal of Democracv, 13(2), 51-65.

Linz, J. J. (1985). Totalitarian and authoritarian regimes. Boulder, Colorado: Lynne Rienner Publishers.

Linz, J. J., \& Stepan, A. (1996). Toward consolidated democracies. Journal of Democracy, $7(2), 14-33$.

Mendras, M. (2007). Russie. L'envers du pouvoir. Paris: Odile Jacob.

Merlin, A. (2007). Le Nord-Caucase au miroir du fédéralisme russe. In A. Merlin (Ed.), Où va la Russie. Bruxelles: Éditions de l'Université de Bruxelles.

Mills, C. (1956). The power elite. Oxford: Oxford University Press.

Mink, G., \& Szurek, J.-C. (1999). La grande reconversion. Le destin des communistes en Europe de l'Est. Paris: Seuil.

Muhin, A. A. (2004). Federal'naïa i reguional'naïa elita Rossii - Kto est' kto v politike i ekonomike. Moscow: Izdate'stvo GNOM i D.

Passeron, J.-C. (1990). Biographies, flux, itinéraires, trajectoires. Revue française de sociologie, $31(1), 3-22$.

Petrov, N. (2002). Seven faces of Putin's Russia: Federal districts as the new level of state territorial composition. Security Dialogue, 33(1), 73-91.

Petrov, N. (2005). How have the presidential envoys changed the Administrative-political balance of Putin's regime? In P. Reddaway \& W. Orttung (Eds.), The dynamics of Russian politics. Putin's reform of federal-regional relations (Vol. 2), Lanham, Maryland: Rowman \& Littlefield.

Przeworski, A. (1979). Some problems in the study of the transition to democracy. Latin American Program, The Wilson Center.

Pudal, B. (2009). Le soviétisme. In A. Cohen, B., Lacroix, \& P. Riutort (Eds.), Nouveau manuel de science politique (pp. 162-172). Paris: La découverte.

Raviot, J.-R. (2006). Comprendre le nouveau régime russe. Strates, 12.

Raviot, J.-R. (2008). Démocratie à la russe, pouvoirs et contre-pouvoirs en Russie. Paris: Ellipses.

Renz, B. (2006). Putin's militocracy? An alternative interpretation of siloviki in contemporary Russian politics. Europe-Asia studies, 58(6), 903-924.

Rivera, D., \& Rivera, S. W. (2008). The Militarization of the Russian Elite Under Putin: How wide and how deep? Department Of Government, Hamilton College. Paper presented at the annual meeting of the MPSA Annual National Conference, Palma House Hotel, Hilton, Chicago, Illinois, April 2008.

Sakwa, R. (2008). Russian politics and society (4th ed.). London, New York: Routledge.

Schedler, A. (2002). The menu of manipulation. Journal of Democracy, 13(2), 36-50.

Stepan, A. (1971). The military in politics: Changing patterns in Brazil. Princeton, NJ: Princeton University Press.

Stepan, A. (1973). Authoritarian Brazil: Origins, policies, and future. New Haven, CT: Yale University Press. 
Surkov, V. (2007). Soverennaïa demokratia. Ot idei k doctrine. Moscow: Evropa.

Szelenyi, I., Wnuk-Lipinski, E., \& Treiman, D. (1995). Circulation or reproduction of elites during post-communist transformation in Russia and Eastern Europe. Theorv and Societv, 24(5), 625-668.

Taylor, B. (2007). Russia's power ministries: Coercion and commerce. Monograph of the Institute for National Security and Counterterrorism, Syracuse University.

The Economist. print edition, (2007). Briefing: Russia under Putin, The making of a neo-KGB state. The Economist, August 25.

Tilly, C. (1992). Coercion, capital and European States, A.D. 990 - 1992 (Rev. ed.). Wiley-Blackwell.

Wagner, A.-C. (2007). Les, classes sociales dans la mondialisation. La découverte, Collection "repères sociologiques".

Weber, M. (1971). Économie et Société. Paris: Plon.

Zalewski, F. (2009). Les transitions démocratiques en Europe centrale et orientale. In A. Cohen, B. Lacroix, \& P. Riutort (Eds.), Nouveau manuel de science politique (pp. 210-217). Paris: La découverte. 